\title{
Status Gizi Ibu dan Berat Badan Lahir Bayi
}

\author{
Nutrition Status and Infant Birth Weight
}

Khaula Karima, Endang L. Achadi

Departemen Gizi Kesehatan Masyarakat Fakultas Kesehatan Masyarakat Universitas Indonesia

\begin{abstract}
Abstrak
Berat badan lahir 2.500 gram yang hingga kini merupakan standar ukuran risiko morbiditas dan mortalitas bayi merupakan faktor risiko penting yang berdampak hingga usia dewasa. Saat ini, bayi dengan berat badan lahir di bawah 3.000 gram dihubungkan dengan risiko penyakit degeneratif pada usia dewasa. Penelitian ini bertujuan mengetahui hubungan berat badan lahir dengan status gizi ibu meliputi berat badan prahamil, pertambahan berat badan selama kehamilan, dan kadar hemoglobin ibu pada trimester ketiga kehamilan. Penelitian kuantitatif dengan desain cross sectional ini menggunakan sumber data sekunder rekam medis Rumah Sakit Ibu dan Anak Budi Kemuliaan Jakarta. Analisis dilakukan secara bivariat dan multivariat menggunakan metode uji chi square dan korelasi regresi. Hasil studi menunjukkan hubungan yang bermakna antara berat badan prahamil dan pertambahan berat badan ibu selama kehamilan dengan berat badan lahir. Setelah dikontrol berbagai variabel lain, analisis regresi logistik ganda menemukan berat badan ibu prahamil, pertambahan berat badan selama kehamilan, usia ibu, dan urutan kelahiran merupakan faktor yang memengaruhi berat badan lahir. Berat badan prahamil ibu merupakan faktor yang paling berpengaruh terhadap berat badan lahir (odds ratio, OR = $6,64)$. Oleh sebab itu, ibu dengan status gizi prahamil kurang yang sedang merencanakan kehamilan perlu lebih diperhatikan.
\end{abstract}

Kata kunci: Berat badan lahir, kehamilan, mortalitas bayi, status gizi ibu

\begin{abstract}
The weight of 2.500 gram is still being used as the cut off point to predict the risk of baby's morbidity and mortality. Recently birth weight of less than 3.000 gram is being rigorously assess as a risk factor for noncommunicable disease in adulthood. Therefore it is important to assess factors that are affecting the fetal growth and development. The objectives of this study is to determine the relationship between infant's birth weight and mother's nutritional status, i.e. pre-pregnancy weight, weight gain during pregnancy, and maternal haemoglobin level in the $3 r d$ trimester as well as several other fac-
\end{abstract}

tors. The study design is cross sectional using secondary data from medical record of Budi Kemuliaan Hospital Jakarta. The result of chi square and correlation regression test shows there is significant relationship between pre-pregnancy weight and weight gain during pregnancy and birth weight. The multiple logistic regression test reveals that pre-pregnancy weight, weight gain during pregnancy, maternal age, and birth order are factors that are effecting birth weight significantly, with pre-pregnancy weight as the dominant factor (odds ratio, $\mathrm{OR}=6,643$ ). Therefore, it is imperative to give more attention to undernourished women who are planning their pregnancy.

Key words: Birth weight, pregnancy, infant mortality, mother nutritional status

\section{Pendahuluan}

Kekurangan gizi yang terjadi selama kehamilan dapat berdampak kumulatif pada status gizi janin yang direpresentasikan oleh berat badan lahir yang tidak optimal. Berbagai penelitian yang selama ini menggunakan 2.500 gram sebagai batas berat badan lahir dihubungkan dengan risiko morbiditas dan mortalitas bayi yang dilahirkan. Akhir-akhir ini, berbagai penelitian menunjukkan berat badan lahir di bawah 3.000 gram memiliki risiko penyakit degeneratif ketika dewasa. ${ }^{1-3}$ Saat ini, satu dari sepuluh balita di Indonesia terlahir dalam kondisi berat badan lahir rendah (BBLR), sehingga dapat diasumsikan bahwa lebih banyak lagi angka bayi dengan berat badan lahir kurang dari 3.000 gram yang berisiko lebih besar mengalami penyakit degeneratif pada usia de-

Alamat Korespondensi: Khaula Karima, Departemen Gizi Kesehatan Masyarakat Gd. F Lt. 2 FKM Universitas Indonesia, Kampus Baru UI Depok 16424, Hp.083896085900, e-mail: khaula.karima.6@gmail.com 
wasa. Hal tersebut perlu diperhitungkan secara cermat, mengingat dampak pada kualitas sumber manusia dan kebutuhan biaya penanggulangan penyakit degeneratif pada tingkat keluarga dan negara yang besar. ${ }^{2}$ Telah diketahui bahwa status gizi ibu berperan sangat penting terhadap status gizi dan kesehatan bayi. Ibu yang kurang gizi akan menyebabkan janin mengalami gangguan pertumbuhan dan fungsi plasenta yang direfleksikan oleh berat dan ukuran plasenta yang relatif lebih kecil. Kurang gizi pada ibu akan mengurangi ekspansi volume darah yang mengakibatkan pemompaan darah dari jantung (cardiac output) yang tidak mencukupi. Hal tersebut mengurangi aliran darah ke plasenta dan berdampak pada ukuran plasenta yang tidak optimal dan mengurangi pengangkutan zat gizi ke janin, sehingga berakibat pertumbuhan bayi yang terhambat (fetal growth retardation). ${ }^{3}$

Status gizi ibu dapat diukur melalui tinggi badan, indeks massa tubuh (IMT) prahamil, pertambahan berat badan selama kehamilan, dan kadar hemoglobin $(\mathrm{Hb})$ ibu. ${ }^{4,5}$ Pertambahan berat badan ibu selama kehamilan secara langsung memengaruhi berat badan lahir dan dipengaruhi oleh berbagai faktor, antara lain status gizi prahamil dan faktor sosiodemografi. ${ }^{6}$ Beberapa penelitian di Indonesia menyatakan berat badan prahamil yang rendah berkorelasi dengan pertambahan berat badan selama kehamilan yang rendah. Sementara, anemia pada ibu hamil berhubungan dengan asupan energi dan makanan mengandung zat besi yang rendah. Kondisi ini dapat berakibat pada pertambahan berat badan ibu selama kehamilan yang tidak maksimal dan peningkatan risiko kelahiran prematur, sehingga ibu lebih berisiko untuk melahirkan bayi dengan berat badan lahir yang tidak optimal.4,6 Tujuan penelitian ini adalah mengetahui hubungan status gizi ibu meliputi berat badan prahamil, pertambahan berat badan selama kehamilan, kadar $\mathrm{Hb}$ ibu pada trimester ketiga kehamilan, serta faktor sosiodemografi, yaitu status bekerja ibu, usia ibu, tingkat pendidikan ibu, urutan kelahiran, jarak kelahiran, dan jenis kelamin bayi dengan berat badan lahir bayi.

\section{Metode}

Penelitian ini menggunakan sumber data sekunder rekam medis pasien rawat inap yang melahirkan di Rumah Sakit Ibu dan Anak (RSIA) Budi Kemuliaan Jakarta pada bulan Januari 2012. Desain penelitian yang digunakan adalah cross sectional yang mengamati dan menganalisis variabel status gizi ibu meliputi berat badan prahamil, pertambahan berat badan selama kehamilan, serta kadar $\mathrm{Hb}$ ibu pada trimester ketiga kehamilan. Beberapa faktor lain yang juga diamati adalah faktor sosiodemografi meliputi status bekerja ibu, usia ibu, tingkat pendidikan ibu, urutan kelahiran, jarak kelahiran, jenis kelamin bayi, dan berat badan lahir bayi. Populasi penelitian adalah seluruh ibu dan bayi yang dilahirkan di RSIA Budi Kemuliaan. Sampel penelitian adalah seluruh ibu dan bayi pasien rawat inap yang melahirkan di RSIA Budi Kemuliaan pada Januari 2012 dengan usia gestasi lebih dari sama dengan 37 minggu, bayi tunggal, dan memeriksa antenatal di RSIA Budi Kemuliaan sejak trimester pertama kehamilan dan mempunyai kelengkapan data pada formulir rekam medis sesuai dengan yang diteliti. Seluruh anggota populasi yang sesuai dengan kriteria inklusi disertakan sebagai sampel dalam penelitian. Rekam medis pasien melahirkan pada periode Januari 2012 adalah 900 pasien, setelah diseleksi dengan kriteria melahirkan dengan usia kehamilan lebih atau sama dengan 37 minggu diperoleh 305 pasien. Namun, diperoleh 118 pasien yang memeriksakan kehamilan di RSIA Budi Kemuliaan sejak trimester pertama kehamilan sehingga dapat diketahui data berat badan prahamil ibu. Instrumen yang digunakan untuk mengumpulkan data adalah formulir check list yang digunakan untuk menyalin data dari rekam medis untuk selanjutnya diolah.

Data usia gestasi diperoleh dari formulir penerimaan pasien, sedangkan data berat badan prahamil ibu diperoleh dari formulir kunjungan pemeriksaan antenatal pada trimester pertama kehamilan. Data pertambahan berat badan ibu selama kehamilan diketahui dengan mengurangi berat badan ibu menjelang melahirkan yang diperoleh dari formulir pemeriksaan antenatal dengan berat badan ibu pada trimester pertama kehamilan. Kadar $\mathrm{Hb}$ ibu diketahui dari resume medis pasien atau hasil pemeriksaan laboratorium yang terlampir di rekam medis. Data anak yang telah dilahirkan ibu, pendidikan, dan pekerjaan ibu diperoleh dari formulir status obstetri ibu, sedangkan data berat badan lahir dan jenis kelamin bayi diperoleh dari formulir ikhtisar persalinan. Analisis data menggunakan uji chi square, uji t, uji regresi korelasi, dan multiple logistic regression.

\section{Hasil \\ Berat Badan Lahir Bayi}

Penelitian ini menujukkan bahwa $35,6 \%$ bayi yang lahir di lokasi penelitian mempunyai berat badan lahir kurang dari 3.000 gram dan 9,3\% bayi lahir dengan berat badan lahir kurang dari 2.500 gram. Namun, untuk angka bayi dengan berat badan lahir kurang dari 3.000 gram di Indonesia tidak diketahui, mengingat data terbaru dari Riset Kesehatan Dasar tahun 2010 tidak mengategorikan berat badan lahir kurang dari 3.000 gram. Rata-rata berat badan lahir bayi yang lahir di lokasi penelitian adalah 3.178 gram.

\section{Status Gizi Ibu}

Rata-rata berat badan ibu prahamil adalah $59 \mathrm{~kg}$ 
Tabel 1. Distribusi Status Gizi Ibu

\begin{tabular}{lcccc}
\hline Variabel & Rata-rata \pm SD & Minimal & Maksimal & $\%$ \\
\hline Berat badan prahamil $(\mathrm{kg})$ & $59 \pm 12,5$ & 38 & 113 & \\
Pertambahan berat badan $(\mathrm{kg})$ & $9,7 \pm 4,4$ & 1 & 22 & \\
$\mathrm{Hb}(\mathrm{cm})$ & $11,5 \pm 1$ & 8,5 & 14,7 & \\
$\mathrm{Hb}<11 \mathrm{~g} / \mathrm{dl}$ & & & & 22,1 \\
$\mathrm{BB}$ prahamil $<50 \mathrm{~kg}$ & & & 66,7 \\
Pertambahan $\mathrm{BB}<10 \mathrm{~kg}$ & & & 59,3 \\
\hline
\end{tabular}

dengan rata-rata pertambahan berat badan selama kehamilan 9,7 kg dan kadar $\mathrm{Hb}$ ibu pada trimester ketiga kehamilan yaitu $11,56 \mathrm{~g} / \mathrm{dl}$ (Tabel 1). Ibu hamil yang mengalami anemia sebesar $22,1 \%$.

Penelitian ini juga menemukan sekitar $66,7 \%$ ibu dengan berat badan prahamil kurang dari $50 \mathrm{~kg}$ yang melahirkan bayi dengan berat badan lahir kurang dari 3.000 gram (Tabel 1). Hasil analisis dengan uji chi square menunjukkan hubungan yang bermakna antara berat badan prahamil dengan berat badan lahir bayi, terdapat perbedaan 39\% antara ibu dengan berat badan prahamil lebih dari $50 \mathrm{~kg}$ dan kurang dari $50 \mathrm{~kg}$ yang mempunyai bayi dengan berat badan lahir di bawah 3.000 gram. Ibu yang mempunyai berat badan prahamil kurang dari $50 \mathrm{~kg}, 5,31$ kali lebih berisiko untuk melahirkan bayi dengan berat badan lahir kurang dari 3.000 gram (Tabel 2).

Pada penelitian ini, sekitar 40,7\% ibu mampu mencapai pertambahan berat badan $10 \mathrm{~kg}$ yang dianjurkan (Tabel 1). Ibu dengan pertambahan berat badan selama kehamilan kurang dari $10 \mathrm{~kg}$ berisiko 2,3 kali untuk melahirkan bayi dengan berat badan lahir kurang dari 3.000 gram (Tabel 2).

Sekitar $74,1 \%$ ibu yang berhasil mencapai pertambahan berat badan lebih dari $10 \mathrm{~kg}$ melahirkan bayi dengan berat badan lebih dari 3.000 gram (Tabel 2). Hasil uji statistik dengan menggunakan uji chi square dan uji regresi korelasi menunjukkan hal yang sama, yaitu terdapat hubungan yang bermakna antara pertambahan berat badan selama kehamilan dengan berat badan lahir (nilai $\mathrm{p}=0,03$ ) dan (nilai $\mathrm{p}=0,019$ ) (Tabel 2 dan Tabel 3). Kadar $\mathrm{Hb}$ ibu pada trimester ketiga kehamilan justru berhubungan negatif setelah dilakukan uji korelasi regresi. Dengan demikian, ibu dengan kadar $\mathrm{Hb}$ pada trimester ketiga kehamilan yang lebih tinggi akan mempunyai berat badan lahir yang lebih rendah, tetapi secara statistik tidak bermakna.

\section{Sosiodemografi dan Jenis Kelamin}

Pada penelitian ini, sekitar $46,6 \%$ ibu bekerja dan sisanya merupakan ibu rumah tangga, tetapi sekitar $65,1 \%$ ibu yang tidak bekerja melahirkan bayi dengan berat badan lahir lebih dari 3.000 gram (Tabel 4). Hasil uji chi square dan uji t menyatakan tidak terdapat hubungan yang bermakna antara status bekerja ibu dengan berat badan lahir (Tabel 2 dan Tabel 5).

Faktor yang memengaruhi pertambahan berat badan ibu selama kehamilan adalah keseimbangan energi yang dipengaruhi oleh asupan energi dan energi yang dikeluarkan. Status pekerjaan ibu di negara berkembang, misalnya ibu yang bekerja sebagai petani akan mengeluarkan energi yang lebih besar daripada ibu yang tidak bekerja. Namun, lokasi penelitian ini adalah perkotaan, sehingga diperkirakan pekerjaan yang dilakukan bukan pekerjaan yang menuntut kegiatan fisik yang tinggi. Sulit untuk memisahkan antara pekerjaan yang mengeluarkan energi lebih tinggi dan pekerjaan yang mengeluarkan energi lebih rendah. Dari gambaran jenis pekerjaan yang dilakukan ibu, sekitar 53,4\% adalah ibu rumah tangga, $36,4 \%$ adalah karyawan, $4,2 \%$ adalah wiraswasta, 3,4\% adalah guru, dan lainnya merupakan dokter, polisi, dan pegawai negeri sipil (PNS) (Tabel 4). Pekerjaan seperti ibu rumah tangga dan karyawan tidak secara jelas dapat menggambarkan status sosial ekonomi dan aktivitas fisik ibu karena posisi ibu di tempat kerja tidak diketahui, sehingga tidak dapat menggambarkan pendapatan dan aktivitas ibu. Status pekerjaan ibu sulit digunakan untuk menggambarkan aktivitas fisik yang dilakukan ibu, sebab status pekerjaan menggambarkan aktivitas yang dibayar atau digaji dengan aktivitas yang tidak digaji. Ibu yang bekerja mungkin mengeluarkan energi yang lebih sedikit dari ibu yang tidak bekerja. Hal yang sama, ibu rumah tangga yang berstatus tidak bekerja kemungkinan mengerjakan pekerjaan rumah tangga yang menuntut kegiatan fisik yang cukup tinggi. Bayi yang lahir dari ibu bekerja mempunyai rata-rata berat badan lahir 3.180,18 gram, tidak jauh berbeda dibandingkan ibu yang tidak bekerja (Tabel 5). Tidak terdapat hubungan yang bermakna antara status bekerja ibu dengan berat badan lahir juga dapat disebabkan oleh variabel lain yang tidak dikontrol.

Penelitian ini justru tidak menemukan hubungan antara tingkat pendidikan ibu dengan berat badan lahir. Uji chi square dan uji korelasi regresi menunjukkan hal yang sama. Sekitar $88,14 \%$ responden pada penelitian ini merupakan ibu dengan tingkat pendidikan di atas sekolah menengah atas (SMA). Hal tersebut disebabkan oleh lokasi penelitian di perkotaan, sehingga akses terhadap pendidikan tidak sesulit di pedesaan. Tingkat pendidikan responden yang cenderung homogen mengurangi variasi data (Tabel 2).

Pendidikan ibu merupakan faktor yang berpengaruh terhadap status gizi ibu yang selanjutnya berpengaruh terhadap berat badan lahir. Mekanisme tersebut tidak terlihat pada penelitian ini, sebab 71,4\% ibu dengan tingkat pendidikan di bawah SMA justru melahirkan bayi dengan berat badan lahir di atas 3.000 gram. Hal tersebut dise- 
Tabel 2. Distribusi Berat Badan Lahir

\begin{tabular}{|c|c|c|c|c|}
\hline \multirow{2}{*}{ Variabel } & \multirow{2}{*}{ Kategori } & \multicolumn{2}{|c|}{ Berat Badan Lahir (\%) } & \multirow{2}{*}{ Nilai $p$} \\
\hline & & $<3.000$ gram & $\geq 3.000$ gram & \\
\hline \multirow[t]{2}{*}{ Berat badan prahamil } & $<50 \mathrm{~kg}$ & 66,7 & 33,3 & $0,000 *$ \\
\hline & $\geq 50 \mathrm{~kg}$ & 27,7 & 72,3 & \\
\hline \multirow[t]{2}{*}{ Peningkatan BB ibu selama hamil } & $<10 \mathrm{~kg}$ & 45,0 & 55,0 & $0,03 *$ \\
\hline & $\geq 10 \mathrm{~kg}$ & 25,9 & 74,1 & \\
\hline \multirow[t]{2}{*}{$\mathrm{Hb}$ ibu trimester ketiga } & $<11 \mathrm{~g} / \mathrm{dl}$ & 38,5 & 61,5 & 0,729 \\
\hline & $\geq 11 \mathrm{~g} / \mathrm{dl}$ & 34,8 & 65,2 & \\
\hline \multirow[t]{2}{*}{ Status bekerja ibu } & Bekerja & 36,4 & 63,6 & 0,87 \\
\hline & Tidak bekerja & 34,9 & 65,1 & \\
\hline \multirow[t]{2}{*}{ Usia ibu } & $<20$ tahun atau $>34$ tahun & 50,0 & 50,0 & 0,14 \\
\hline & $20-34$ tahun & 32,7 & 67,3 & \\
\hline \multirow[t]{2}{*}{ Pendidikan ibu } & $<$ SMA sederajat & 28,6 & 71,4 & 0,768 \\
\hline & $\geq$ SMA sederajat & 36,5 & 63,5 & \\
\hline \multirow[t]{2}{*}{ Urutan kelahiran } & Anak pertama & 41,3 & 58,7 & 0,168 \\
\hline & Anak kedua & 29,1 & 70,9 & \\
\hline \multirow[t]{2}{*}{ Jarak kelahiran } & $<2$ tahun & 27,3 & 32,7 & 1,000 \\
\hline & $\geq 2$ tahun & 29,5 & 70,5 & \\
\hline \multirow[t]{2}{*}{ Jenis kelamin bayi } & Perempuan & 33,9 & 66,1 & 0,701 \\
\hline & Laki-laki & 37,3 & 62,7 & \\
\hline
\end{tabular}

Tabel 3. Korelasi dan Regresi Status Gizi Ibu, Sosiodemografi, dan Jenis Kelamin dengan Berat Badan Lahir Bayi

\begin{tabular}{llll}
\hline Variabel & $\mathbf{R}$ & $\mathbf{R}^{\mathbf{2}}$ & Nilai $\mathbf{p}$ \\
\hline Berat badan prahamil ibu (kg) & 0,411 & 0,169 & $0,000^{*}$ \\
Peningkatan berat badan ibu selama kehamilan (kg) & 0,217 & 0,047 & $0,019^{*}$ \\
Kadar Hb ibu (mg/dl) & $-0,104$ & 0,011 & 0,261 \\
Usia ibu (tahun) & $-0,073$ & 0,005 & 0,432 \\
Urutan kelahiran bayi & 0,064 & 0,004 & 0,488 \\
Jarak kelahiran (tahun) & $-0,324$ & 0,105 & $0,016^{*}$ \\
Lama pendidikan (tahun) & 0,076 & 0,006 & 0,413 \\
Usia ibu (tahun) & $-0,073$ & 0,005 & 0,432 \\
\hline
\end{tabular}

Tabel 4. Gambaran Sosiodemografi dan Jenis Kelamin Bayi

\begin{tabular}{|c|c|c|}
\hline Variabel & Kategori & $\%$ \\
\hline \multirow[t]{3}{*}{ Status bekerja ibu } & Tidak bekerja (ibu rumah tangga) & 53,4 \\
\hline & Karyawan & 36,4 \\
\hline & Lain-lain (wirausaha, guru, PNS, polisi, dokter) & 10,2 \\
\hline \multirow[t]{4}{*}{ Tingkat pendidikan } & $\mathrm{SD}$ & 3,4 \\
\hline & SMP & 8,5 \\
\hline & SMA & 51,7 \\
\hline & Perguruan tinggi & 36,4 \\
\hline \multirow[t]{3}{*}{ Usia ibu } & $<20$ tahun & 1,7 \\
\hline & $20-34$ tahun & 83,1 \\
\hline & $>34$ & 15,3 \\
\hline \multirow[t]{2}{*}{ Urutan kelahiran } & 1 & 53,4 \\
\hline & 2 atau lebih & 46,6 \\
\hline \multirow[t]{2}{*}{ Jenis kelamin } & Laki-laki & 50,0 \\
\hline & Perempuan & 50,0 \\
\hline
\end{tabular}

babkan status gizi ibu merupakan faktor yang lebih dominan memengaruhi berat badan lahir. Uji chi square antara usia ibu dengan berat badan prahamil dan pertambahan berat badan menunjukkan hubungan yang tidak bermakna, sekitar 78,6\% ibu dengan tingkat pendidikan kurang dari SMA justru mempunyai berat badan pra- hamil lebih dari $50 \mathrm{~kg}$. Selain itu, tingkat pendidikan tidak selalu merepresentasikan pengetahuan ibu tentang gizi ibu hamil (Tabel 2).

Uji korelasi regresi menunjukkan hubungan negatif antara usia ibu dengan berat badan lahir, padahal seharusnya positif (Tabel 3). Setelah data berat badan lahir yang ekstrem dikeluarkan, didapatkan hubungan positif. Dengan demikian, ibu yang lebih muda mempunyai bayi dengan berat badan lahir yang lebih ringan. Hubungan yang tidak bermakna juga dapat disebabkan oleh jumlah ibu yang berusia kurang dari 20 tahun rendah $(1,7 \%)$ dan kekuatan uji variabel ini sangat rendah $(4,26 \%)$. Padahal, ibu pada usia ini lebih berisiko tidak mencapai pertambahan berat badan yang direkomendasikan, sehingga melahirkan bayi dengan berat badan lahir yang lebih rendah (Tabel 2).

Uji logistik regresi ganda menemukan usia ibu merupakan faktor perancu yang memengaruhi berat badan prahamil ibu. Ibu dengan usia $<20$ tahun dan $>34$ tahun berisiko 3,8 kali lebih besar melahirkan bayi dengan berat badan lahir kurang dari 3.000 gram (Tabel 6). Untuk mengetahui lebih jelas hubungan usia ibu dengan berat 
Tabel 5. Rata-rata Berat Badan Lahir Berdasarkan Status Bekerja Ibu dan Jenis Kelamin Bayi

\begin{tabular}{llllll}
\hline Variabel & Kategori & Mean & SD & SE & Nilai p \\
\hline \multirow{2}{*}{ Status bekerja } & Ya & $3.180,2$ & 501,304 & 67,596 & 0,973 \\
& Tidak & $3.177,3$ & 438,2 & 55,2 & \\
Jenis kelamin & Perempuan & $3.186,9$ & 489,84 & 63,8 & 0,848 \\
& Laki-laki & $3.170,3$ & 446,26 & 58,2 & \\
\hline
\end{tabular}

Tabel 6. Model Akhir Analisis Regresi Logistik Ganda Model Risiko Antarvariabel Independen dengan Berat Badan Lahir

\begin{tabular}{|c|c|c|c|c|c|c|}
\hline \multirow{2}{*}{ Variabel } & \multirow{2}{*}{ B } & \multirow{2}{*}{ Nilai $p$} & \multirow{2}{*}{$\operatorname{Exp}(B)$} & \multicolumn{2}{|c|}{ 95\% CI } & \multirow{2}{*}{$\mathbf{R}^{2}$} \\
\hline & & & & Lower & Upper & \\
\hline Berat badan prahamil & 1,894 & 0,000 & 6,643 & 2,335 & 18,897 & \\
\hline Urut kelahiran & 0,821 & 0,085 & 2,272 & 0,893 & 5,780 & 0,254 \\
\hline Usia ibu & 1,336 & 0,024 & 3,804 & 1,194 & 12,113 & \\
\hline Pertambahan berat badan & 1,025 & 0,022 & 2,786 & 1,160 & 6,694 & \\
\hline Constant & $-7,859$ & 0,000 & 0,000 & & & \\
\hline
\end{tabular}

badan prahamil dan pertambahan berat badan ibu, dilakukan uji chi square antara usia dengan berat badan prahamil dan pertambahan berat badan selama kehamilan. Tidak ditemukan hubungan yang bermakna di antara keduanya, tetapi sekitar $60 \%$ ibu dengan usia kurang dari 20 tahun dan lebih dari 34 tahun mengalami pertambahan berat badan selama kehamilan kurang dari 10 $\mathrm{kg}$ (Tabel 4).

Sekitar 85,5\% ibu yang melahirkan anak kedua atau lebih mempunyai berat badan prahamil lebih dari $50 \mathrm{~kg}$, sehingga multipara cenderung lebih berat daripada primipara. Setelah dikontrol berbagai variabel, uji regresi logistik ganda menyimpulkan bahwa urutan kelahiran merupakan faktor yang berhubungan dengan berat badan lahir bayi (Tabel 6). Anak pertama berisiko 2,27 kali lebih besar untuk lahir dengan berat badan lahir kurang dari 3.000 gram. Penelitian ini menemukan berat badan prahamil dan pertambahan berat badan selama kehamilan merupakan faktor yang berhubungan bermakna dan faktor jarak kelahiran tidak berhubungan bermakna dengan berat badan lahir. Untuk mengetahui hubungan jarak kelahiran terhadap berat badan sebelum hamil sebagai faktor yang paling memengaruhi berat badan lahir pada penelitian ini, dilakukan uji chi square antara jarak kelahiran dengan berat badan prahamil dan ternyata tidak berhubungan bermakna (Tabel 5). Semua ibu yang melahirkan bayi dengan jarak kelahiran kurang dari dua tahun mempunyai berat badan prahamil yang baik ( $\geq 50 \mathrm{~kg})$.

Pada penelitian ini terdapat $50 \%$ bayi laki-laki dan $50 \%$ bayi perempuan (Tabel 5 ). Tidak terlihat hubungan yang bermakna antara jenis kelamin dengan berat badan lahir (Tabel 6). Hal tersebut berbeda dengan teori yang berkembang selama ini, berat badan lahir bayi laki-laki lebih tinggi daripada bayi perempuan.

Berdasarkan hasil uji multivariat, terdapat empat faktor yang memengaruhi berat badan lahir bayi di RSIA Budi Kemuliaan Jakarta pada Januari 2012, yaitu berat badan prahamil ibu, pertambahan berat badan ibu selama kehamilan, usia ibu, dan urutan kelahiran. Keempat variabel tersebut menjelaskan berat badan lahir bayi sebesar $25,4 \%$, sedangkan $74,6 \%$ lainnya dijelaskan oleh variabel lain yang tidak dimasukkan dalam penelitian ini (Tabel 6).

\section{Pembahasan}

Penelitian di Indramayu mengemukakan bahwa ibu dengan tingkat pendidikan lebih rendah dari SMP mempunyai berat badan yang lebih rendah dibandingkan ibu dengan tingkat pendidikan lebih tinggi. ${ }^{4}$ Ibu dengan pertambahan berat badan $<10 \mathrm{~kg}$ dengan status gizi underweight berisiko 2,1 kali lebih besar untuk melahirkan bayi yang lebih ringan daripada ibu yang mengalami pertambahan berat badan antara $10-$ 15 kg. ${ }^{6}$

Penelitian ini menunjukkan bahwa $35,6 \%$ bayi yang lahir mempunyai berat badan lahir kurang dari 3.000 gram dan 9,3\% bayi lahir dengan berat badan lahir kurang dari 2.500 gram. Angka ini masih di bawah angka bayi BBLR di Indonesia, yaitu 11,1\% dan hampir sama dengan angka BBLR di Jakarta, yaitu 9,1\%.7

Faktor berat badan prahamil dan tinggi badan ibu yang dapat diwakilkan oleh IMT prahamil ibu perlu diketahui karena IMT dan tinggi badan berpengaruh besar terhadap berat badan lahir. ${ }^{8}$ Hasil penelitian sebelumnya menyatakan bahwa IMT prahamil merupakan prediktor 
berat badan lahir. Rekomendasi pertambahan berat badan lebih tepat dapat diukur untuk tiap individu berdasarkan IMT prahamil ibu. ${ }^{8}$ Namun, karena ketiadaan data tinggi badan ibu, hal tersebut tidak dapat dianalisis. Oleh sebab itu, pada penelitian ini digunakan berat badan prahamil untuk memperkirakan risiko BBLR. ${ }^{6}$ Berat badan prahamil menggambarkan cadangan energi yang dimiliki ibu sebagai sumber zat gizi bagi janin. ${ }^{8}$ Temuan ini menyatakan bahwa berat badan prahamil merupakan prediktor berat badan lahir. Hal ini merupakan hal yang wajar, mengingat ibu dengan berat badan prahamil yang lebih rendah harus mencapai pertambahan berat badan yang lebih tinggi dibandingkan ibu dengan berat badan prahamil yang lebih tinggi sehingga ibu dengan berat badan prahamil yang lebih rendah akan mengalami kesulitan untuk mencapai pertambahan berat badan ideal yang harus dicapai. Faktor sosiodemografi meliputi usia ibu, paritas, dan status sosial ekonomi dapat diukur dari pendapatan, tingkat pendidikan, dan pekerjaan. ${ }^{9}$

Hasil penelitian ini hampir sama dengan penelitian sebelumnya bahwa rata-rata berat badan lahir bayi di beberapa rumah sakit di Jakarta adalah 3.152,27 gram. ${ }^{9}$ Bayi yang lahir cukup bulan ( $\geq 37$ minggu) namun mempunyai berat badan lahir kurang mengindikasikan terjadinya keterlambatan pertumbuhan saat masih janin. ${ }^{8}$ Bayi dengan berat badan lahir kurang dari 2.500 gram mempunyai risiko tinggi terhadap kejadian mortalitas dan morbiditas akibat penyakit infeksi, underweight, pendek (stunted), atau sangat kurus (wested) pada masa anak-anak. Bayi yang lahir dengan berat badan $2.000-2.499$ gram mempunyai risiko 4 kali untuk mengalami kematian neonatal daripada bayi yang lahir dengan berat badan 2.500 - 2.999 gram dan 10 kali lebih berisiko untuk meninggal dari bayi dengan berat badan lahir 3.000 - 3.499 gram. ${ }^{10}$ Berat badan lahir yang lebih rendah dari 3.000 gram juga mempunyai korelasi dengan peningkatan risiko penyakit degeneratif. Studi yang pertama kali digagas oleh David Barker ini telah dilakukan di berbagai negara dan menyimpulkan hal yang sama.

Hipotesis thriftyphenotype phenomena menyatakan asosiasi epidemiologis antara pertumbuhan janin yang buruk dengan penyakit diabetes melitus tipe dua dan sindrom metabolik pada masa dewasa adalah dampak dari kekurangan gizi pada masa dalam kandungan. Pada keadaan kurang gizi, janin akan beradaptasi dengan cara "menghemat" penggunaan zat gizi yang ada. ${ }^{1}$ Kondisi ini menghasilkan perubahan metabolisme glukosa-insulin yang permanen. Risiko ini lebih tinggi pada wanita atau pria yang mempunyai berat badan lahir kurang dari 3.000 gram. Penelitian di Amerika juga menyimpulkan berat badan lahir yang tidak optimal berhubungan dengan disfungsi endotel pada usia dewasa muda dan da- pat meningkatkan risiko aterosklerosis di kemudian hari. ${ }^{11}$

Hubungan antara pertumbuhan bayi dalam janin dengan penyakit degeneratif merupakan konsekuensi lingkungan pertumbuhan janin yang tidak optimal sehingga genotipe menghasilkan bentuk fisiologis dan morfologis yang tidak optimal. Teori developmental plasticity yang berarti bahwa janin sangat fleksibel terhadap lingkungan, termasuk lingkungan gizi, merupakan suatu fenomena yang berakibat pada perubahan epigenetik dan bersifat permanen. Penelitian terbaru menyimpulkan bahwa pertumbuhan yang lambat pada bayi dan pertambahan berat badan yang cepat pada masa anak-anak (mismatch) berdampak pada peningkatan risiko penyakit degeneratif ketika dewasa. ${ }^{12}$

Berat badan prahamil ibu merefleksikan potensi simpanan gizi untuk tumbuh kembang janin sehingga dapat menjadi acuan untuk menentukan intervensi yang dapat dilakukan. ${ }^{8,12}$ Penelitian Achadi, ${ }^{4}$ di Indramayu menyebutkan rata-rata berat badan prahamil ibu adalah 46,0 kg. ${ }^{13}$ Namun, karena nilai ambang batas berat badan lahir dalam penelitian ini bukan 2.500 gram dan ibu mempunyai rata-rata berat badan prahamil $59 \mathrm{~kg}$ maka nilai ambang batas yang diambil adalah $50 \mathrm{~kg}$. Hubungan antara berat badan ibu prahamil dengan berat badan lahir bayi tergolong erat dan berpola positif yang berarti bahwa semakin tinggi berat badan prahamil, ibu semakin berpotensi melahirkan bayi dengan berat badan lahir yang lebih berat. Hal ini sejalan dengan penelitian di Skotlandia yang menyimpulkan bahwa ibu yang lebih berat dan lebih tinggi rata-rata mempunyai bayi 500 gram lebih berat dibandingkan dengan bayi yang dilahirkan ibu yang lebih kurus dan lebih pendek. ${ }^{14}$ Penelitian Yongki, ${ }^{9}$ di Jakarta juga menyimpulkan hal yang sama. Kleinman, ${ }^{15}$ mengemukakan bahwa rata-rata pertambahan berat badan ibu selama kehamilan untuk ibu dengan berat badan prahamil normal adalah $10 \mathrm{~kg}$.

Pada penelitian ini, seluruh ayah berstatus bekerja sehingga ibu yang bekerja akan menambah pendapatan keluarga. Ibu yang tidak bekerja dan berpendapatan rendah mengasup lebih sedikit protein dan zink. Namun, beberapa penelitian menyatakan tidak terdapat hubungan antara wanita bekerja dengan pendapatan rendah dengan asupan yang lebih bergizi.6,14 Pada penelitian ini, terdapat $83,1 \%$ ibu dengan usia 20 - 34 tahun yang merupakan usia yang baik untuk hamil.6,16 Penelitian ini menunjukkan tidak terdapat hubungan yang bermakna antara usia ibu dengan berat badan lahir bayi. Usia ibu merupakan faktor risiko independen, yang hanya berperan sebagai faktor risiko dengan faktor lain. ${ }^{6}$ Hubungan usia muda saat hamil dan berat badan lahir dipengaruhi oleh faktor lain seperti kemiskinan dan faktor sosial lain. ${ }^{17}$ Beberapa studi menunjukkan hubungan antara 
pekerjaan dengan aktivitas fisik berhubungan dengan outcome kehamilan yang buruk dikontrol oleh asupan energi, sehingga dapat menjelaskan pengaruh aktivitas fisik terhadap outcome kehamilan. ${ }^{18}$

Jarak kelahiran dengan pertambahan berat badan pada masa kehamilan menunjukkan hasil yang bermakna, tetapi sekitar $61,4 \%$ ibu yang melahirkan bayi dengan jarak kelahiran lebih dari dua tahun justru mengalami pertambahan berat badan kurang dari $10 \mathrm{~kg}$. Hal ini dipertegas oleh hasil korelasi regresi yang menyatakan hubungan negatif antara jarak kelahiran dengan berat badan lahir. Jarak kelahiran yang semakin pendek berpeluang menyebabkan bayi dengan berat badan lahir yang lebih tinggi. Jarak antara kelahiran sebelumnya dan konsepsi yang rendah ( $<12$ bulan) atau terlalu lama ( $>$ 37 bulan) dapat meningkatkan risiko outcome kehamilan yang kurang baik pada kasus primipara maupun multipara. ${ }^{19}$

Selama kehamilan, batas normal kadar $\mathrm{Hb}$ ibu berbeda-beda, tergantung pada usia kehamilan. Jika digambarkan dalam sebuah grafik, perubahan kadar $\mathrm{Hb}$ ibu selama kehamilan akan berbentuk U. Kadar Hb ibu akan menurun pada trimester kedua kehamilan akibat hemodilusi dan meningkat lagi pada trimester ketiga kehamilan. Hemodilusi disebabkan oleh peningkatan plasma darah ibu yang lebih besar daripada pertambahan sel darah merah. Ibu hamil yang mempunyai kadar $\mathrm{Hb}<11$ $\mathrm{g} / \mathrm{dl}$ tergolong anemia. ${ }^{20}$ Kondisi anemia pada kehamilan dapat berakibat pada pertambahan berat badan ibu selama kehamilan yang tidak maksimal dan peningkatan risiko kelahiran prematur. ${ }^{8}$ Teori lain menyebutkan bahwa anemia defisiensi besi saat kehamilan mengurangi penyimpanan zat besi pada janin dan dapat berlanjut hingga bayi berusia satu tahun. ${ }^{21}$ Pada penelitian ini, proporsi bayi yang lahir dengan berat badan $<3.000$ gram tidak begitu berbeda antara ibu anemia dengan tidak anemia. Selama trimester ketiga kehamilan, kadar $\mathrm{Hb}$ ibu (kecuali dengan pertambahan berat badan yang adekuat) tidak merepresentasikan berat badan lahir bayi. ${ }^{22}$

Korelasi negatif antara kadar $\mathrm{Hb}$ ibu dengan berat badan lahir juga ditemukan di Mesir. ${ }^{5}$ Wanita dengan penurunan kadar $\mathrm{Hb}$ yang tinggi pada trimester ketiga berpeluang lebih tinggi untuk mempunyai bayi dengan berat badan lahir yang tinggi karena kegagalan ekspansi plasma darah. Sulit untuk membedakan anemia defisiensi besi yang sesungguhnya dengan anemia fisiologis yang dialami ibu hamil sehingga kadar $\mathrm{Hb}$ yang tinggi mungkin menggambarkan kegagalan ekspansi plasma darah atau hemodilusi dan kadar $\mathrm{Hb}$ yang rendah justru menggambarkan anemia fisiologis yang dialami ibu hamil. ${ }^{22}$ Pada penelitian ini, tidak dapat diketahui secara pasti apakah ibu mengalami kegagalan ekspansi plasma darah atau tidak, mengingat tidak terdapat data kadar $\mathrm{Hb}$ ibu pada trimester pertama dan kedua kehamilan.

Sebagian teori menyatakan stres secara fisiologis dan psikologis berhubungan dengan kondisi sosial ekonomi yang rendah, sehingga dapat meningkatkan risiko komplikasi pada masa kehamilan yang berdampak gagal tumbuh pada janin. Mekanisme lain adalah kemiskinan yang berdampak pada malnutrisi akibat akses yang minim terhadap makanan dan layanan kesehatan. Selain itu, wanita dengan kondisi sosial ekonomi rendah cenderung lebih pendek dibandingkan dengan wanita dengan status sosial ekonomi yang lebih baik. ${ }^{17}$ Selain aspek sosioekonomi, beberapa penelitian mengungkapkan status bekerja ibu menggambarkan aktivitas fisik ibu. Aktivitas fisik yang terlalu tinggi dapat mengurangi aliran darah ke plasenta sehingga mengurangi suplai oksigen dan zat gizi ke janin. ${ }^{2,8}$

Usia ibu yang umumnya sangat muda, masih dalam masa pertumbuhan, lebih berisiko untuk melahirkan bayi dengan berat badan lahir yang lebih ringan. Selain itu, terjadi kompetisi zat gizi antara bayi dan ibunya sebab ibu yang masih tumbuh memerlukan zat gizi yang tinggi. ${ }^{8}$ Usia yang lebih tua saat hamil dan melahirkan dapat meningkatkan risiko komplikasi kehamilan, seperti tekanan darah tinggi, diabetes melitus, yang dapat meningkatkan risiko morbiditas setelah masa kehamilan. 6,8

Penelitian ini memperlihatkan hubungan yang tidak bermakna antara urutan kelahiran dan berat badan lahir bayi. Uji korelasi regresi menunjukkan hubungan positif, semakin tinggi urutan kelahiran bayi, semakin tinggi berat badan bayi anak pertama yang biasanya lahir dari ibu berusia lebih muda. ${ }^{8}$ Usia ibu bukan faktor independen outcome kehamilan, tetapi ibu yang melahirkan pada usia remaja, umumnya berstatus gizi lebih rendah daripada ibu yang lebih tua. Akan tetapi, pada penelitian ini usia ibu tidak dikontrol.

Jarak kelahiran yang terlalu dekat berhubungan dengan kesiapan fisiologis ibu, hormonal, dan cadangan lemak untuk kembali hamil dan melahirkan. ${ }^{8}$ Sebagian besar BBLR dilahirkan oleh ibu dengan jarak kelahiran jauh ( $\geq 2$ tahun) dan hanya sebagian kecil yang dilahirkan oleh ibu dengan jarak kelahiran dekat ( $<2$ tahun). Meskipun teori menyebutkan bahwa jarak kelahiran yang dekat berisiko lebih besar melahirkan BBLR, tetapi tidak tertutup kemungkinan ibu yang hamil dengan jarak kelahiran jauh juga berisiko melahirkan bayi dengan BBLR. Ibu dengan jarak kelahiran dekat juga mempunyai faktor risiko selain melahirkan bayi BBLR, seperti komplikasi kehamilan, penyakit, gizi kurang, dan anemia. Meskipun hanya sebagian kecil, jarak kelahiran dekat dapat menjadi faktor risiko terhadap kejadian BBLR, apalagi jika disertai faktor lainnya. ${ }^{23}$

Penelitian ini menunjukkan tidak terdapat hubungan 
yang bermakna antara jarak kelahiran bayi dengan berat badan lahir apabila dilakukan uji chi square. Namun, uji korelasi regresi menunjukkan jarak kelahiran bayi mempunyai hubungan yang bermakna dengan berat badan lahir. Studi menemukan bahwa terdapat asosiasi antara wanita yang telah lama tidak hamil dengan berat badan prahamil yang rendah. ${ }^{24}$ Meta analisis pada jarak kehamilan 18 - 23 bulan menyebutkan bahwa jarak kelahiran kurang dari 6 bulan meningkatkan risiko BBLR, kelahiran prematur, dan small for gestational age, sedangkan jarak kelahiran $6-17$ bulan dan lebih dari 59 bulan berhubungan dengan peningkatan risiko BBLR. ${ }^{25}$

\section{Kesimpulan}

Di RSIA Budi Kemuliaan Jakarta, angka bayi dengan berat badan lahir kurang dari 2.500 gram pada Januari 2012 lebih rendah dari angka nasional. Angka bayi dengan berat badan lahir kurang dari 3.000 gram tergolong tinggi. Analisis logistik regresi ganda menunjukkan berat badan prahamil ibu, pertambahan berat badan ibu selama kehamilan, usia ibu, dan urutan kelahiran bayi berhubungan dengan berat badan lahir bayi. Berat badan prahamil ibu merupakan faktor yang paling memengaruhi berat badan lahir. Ibu dengan berat badan prahamil kurang dari $50 \mathrm{~kg}$ berisiko 6,64 kali lebih besar untuk melahirkan bayi dengan berat badan lahir kurang dari 3.000 gram.

\section{Saran}

Intervensi terbaik untuk mencapai berat badan lahir bayi yang ideal dapat dilakukan dengan mempersiapkan status gizi prahamil ibu.

\section{Ucapan Terima Kasih}

Penulis mengucapkan terima kasih atas dukungan pemimpin RSIA Budi Kemuliaan Jakarta, khususnya dr. Retno Hadiati; Agus Rahmanto, SKM MARS; dr. Ambun Suri; dan rekan-rekan di Rekam Medis RSIA Budi Kemuliaan.

\section{Daftar Pustaka}

1. Hales CN, Barker DJP. The thrifty phenotype hypothesis. British Medical Bulletin. 2001; 60: 5-20.

2. World Health Organization. Promoting optimal fetal development report of a technical consultation. Geneva: World Health Organization; 2006

3. Rosso P. Nutrition and metabolism in pregnancy, mother, and fetus. New York: Oxford University Press; 1990.

4. Achadi EL, Hansell MJ, Sloan NL, Anderson MA. Women's nutritional status, iron consumption, and weight gain during pregnancy in relation to neonatal weight and length in West Java, Indonesia. International Journal of Gynecology and Obsterics. 1995; 48 Suppl: 103-19.

5. Hasan NE, Shalaan AH, El-Masry SA. Relationship between maternal characteristics and neonatal birth size in Egypt. Eastern Mediterranean Health Journal. 2011; 17 (4).

6. Institute of Medicine. Weight gain during pregnancy: reexamining the guidelines. Washington DC: National Academy of Science; 2009.

7. Kementerian Kesehatan Republik Indonesia. Riset kesehatan dasar. Jakarta: Kementerian Kesehatan Republik Indonesia; 2010.

8. Kramer MS. Determinant of low birth weight: methodological assessment and meta-analysis. Bulletin of the World Health Organization. 1987; 65 (5): 663-737.

9. Yongki. Analisis pertambahan berat badan ibu hamil berdasarkan status sosial ekonomi dan status gizi serta hubungannya berat bayi baru lahir [disertasi]. Bogor: Fakultas Gizi Masyarakat Institut Pertaian Bogor; 2007.

10. United Nations Administrative Committee on Coordination SubCommittee on Nutrition. Low birth weight. Report of meeting Nutrition Policy Paper. Dhaka: World Health Orgaization; 2000. Report No. 18.

11. Leeson CP, Kattenhorn M, Morley R, Lucas A, Deanfield JE. Impact of low birth weight and cardiovascular risk factors on endothelial function in early adult life. Circulation. 2001; 103: 1264-8. Available from: http://www.circ.ahajournals.org.

12. Gluckman PD, Hanson MA, Spencer HG, Bateson P. Environmental influences during development and their later consequences for health and disease: implications for the interpretation of empirical studies. Proceedings Biological Sciences/The Royal Society. 2005; 272: 671-7.

13. Achadi EL. Pengukuran status gizi ibu hamil dan ibu menyusui dengan metode antropometri. Nutrire Diaita. 2008; 1 (1): 49-76.

14. Cleary-Goldman J, Malone FD, Vidaver J, Ball RH, Nyberg DA, Comstock $\mathrm{CH}$, et al. Impact of maternal age on obstetric outcome. Obstetrics and Gynecology. 2005; 105 (5 Pt 1): 983-90.

15. Klainman. Maternal and child nutrition and pregnancy outcomes. In: Krasovec K, Anderson MA. Washington DC: PAHO; 1991.

16. United Nations Children's Fund, World Health Organization. Low birthweight: country, regional, and global estimates. United Nations Children's Fund, World Health Organization: New York and Geneva; 2004.

17. Geronimus AT, Korenman S. Maternal youth or family background? On the health disadvantages of infants with teenage mothers. American Journal of Epidemiology. 1993; 137 (2): 213-25.

18. Pivarnik JM. Potential effects of maternal physical activity on birth weight: brief review. 1998; 30 (3): 400-6.

19. Asiah S, Suwoyo, Mahaendriningtyastuti. Karakteristik bayi berat lahir rendah (BBLR) sampai tribulan II tahun 2009 di Kota Kediri. J Penelitian Kesehatan Suara Forikes. 2010; 1 (3): 210-22. Diunduh dari: http://www.jurnal.pdii. lipi. go.id/admin/jurnal/1310210222.pdf.

20. Centers for Disease Control and Prevention. Recommendations to prevent and control iron deficiency in the United States. Morbidity and Mortality Weekly Report. 1998; 47 (RR-3): 1-36.

21. Allen LH. Anemia and iron deficiency: effects on pregnancy outcome. American Journal of Clinical Nutrition. 2000; 71 (5 Suppl): 1280S-4S.

22. Scholl T, Hediger ML. Anemia and iron-deficiency anemia: compilation of data on pregnancy outcome. The American Journal of Clinical Nutrition. 1994; 59: 492-501.

23. Pebley AR, DaVanzo J. Maternal depletion and child survival in Guatemala and Malaysia. Presented at the annual meeting of the 
Population Association of America, April 21-23 1988; New Orleans, LA. In: Winkvist A. A new definition of maternal depletion syndrome. American Journal of Public Health. 1992; 82691-694.

24. Agudelo AC, Conde-Agudelo A, Rosas-Bermudez A, Kafury-Goeta AC. Birth spacing and risk of adverse perinatal outcomes a meta-analysis.
The Journal of The American Medical Association. 2006; 295 (15): 1809-23.

25. Fikree FF, Berendes HW. Risk factors for term intrauterine growth retardation: community-based study in Karachi Berendes. Bulletin of the World Health Organization. 1994; 72 (4): 581-7. 